The University of Maine

DigitalCommons@UMaine

Communication and Journalism Faculty

Scholarship

Communication and Journalism

2010

\title{
A Profitable Public Sphere: The Creation of the New York Times Op-Ed Page
}

Michael J. Socolow

University of Maine, michael.socolow@maine.edu

Follow this and additional works at: https://digitalcommons.library.umaine.edu/cmj_facpub

Part of the Business and Corporate Communications Commons, Journalism Studies Commons, Other Film and Media Studies Commons, Other History Commons, and the Publishing Commons

\section{Repository Citation}

Socolow, Michael J., "A Profitable Public Sphere: The Creation of the New York Times Op-Ed Page" (2010). Communication and Journalism Faculty Scholarship. 2.

https://digitalcommons.library.umaine.edu/cmj_facpub/2 


\title{
A PROFITABLE PUBLIC SPHERE: THE CREATION OF THE NEW YORK TIMES OP-ED PAGE
}

\author{
ByMichael/. Socolow
}

This study utilizes archival and other primary materials to describe the development of the New York Times op-ed page. This innovativeforum for commentary, which premiered in September 1970, is examined through the lenses of Jiirgen Habermas' public sphere theory and economic concerns in the American newspaper industry. The page provided a significant source of revenue and diversified social, cultural, and political news analysis. Times executives sought to serve the public interest while considering corporate profits.

On September 21, 1970, the New York Times began publishing its op-ed page. "We hope," the editors wrote, "that a contribution may be made toward stimulating new thought and provoking new discussion on public problems." ${ }^{1}$ This new forum of opinion and commentary was soon imitated by other newspapers. The importance of the op-ed page is easily recognized, but historians have not fully investigated its origins. Nor has the creation of the op-ed essay as a specific genre of journalistic writing been adequately examined.

This article analyzes the historical development of both the op-ed essay and the op-ed forum at the Times within the framework. of Jurgen Habermas' public sphere theory and the context of industry needs and trends. The Times designed the page to be both profitable and intellectually stimulating. Although these objectives could be in conflict, newsroom managers worked to make their project viable and vibrant.

The Times' effort synthesized various antecedents and editorial visions. Journalistic innovation is usually complex, and typically involves multiple external factors. The Times op-ed page appeared in an era of democratizing cultural and political discourse and of economic distress for the company itself. The newspaper's executives developed a place for outside contributors with space reserved for sale at a premium rate for additional commentaries and other purposes.

Participants in the process have discussed the personalities involved, yet histories of the New York Times as well as biographies and memoirs provide only cursory treatments of the page's origins. ${ }^{2}$ In his study of organizational communication, however, Chris Argyris did

Michael J. Socolow is an assistant professor in the Department of Communication and Journalism at the University of Maine. 
reveal information about the decision making. ${ }^{3}$ In general, interviews, oral histories, secondary sources, and other accounts provide fragmented narratives of interpersonal rivalries and organizational negotiations. The most recent attempt to recount the history of the op-ed page follows the same pattern, relying upon a single oral history and secondary sources. ${ }^{4}$ Previous research lacks a comprehensive analysis of the philosophical issues and business concerns that were raised.

Media scholars have discussed the apparent conflict between making profits and serving the public interest. ${ }^{5}$ Can both goals be complementary? How and why did the New York Times executives reach their conclusions about making money and serving democracy with their innovation? Were they trying to contribute to what Jurgen Habermas described as a bourgeois public sphere, an arena of rational, critical discourse designed to invite and facilitate civic and cultural participation?6

John B.
Oakes
and the
Public
Sphere

John B. Oakes and the Sphere

In the summer of 1956, John B. Oakes, a member of the editorial board of the New York Times, received a letter from his friend Ed Barrett. Barrett, who had been an assistant secretary of state specializing in propaganda and would later become dean of the Columbia School of Journalism, was working in public relations. His client, the Suez Canal Company, wanted to publish an article detailing its position on the Egyptian government's seizure of the canal. Barrett had drafted a short piece and submitted it to Oakes for publication. Oakes liked the essay but was forced to inform Barrett that the Times could not publish it. "We just didn't have a place for that kind of fairly short piece," he later remembered. Barrett then turned to the New York Herald Tribune, which printed the commentary (under the name of Francois Charles-Roux, chairman of the board of the Suez Canal Company) in a spot occasionally reserved for outside contributors on its editorial page.7

Oakes later regarded that experience as the origin of the New York Times' op-ed page. He also acknowledged that his idea was not particularly novel; it was modeled on the page of commentary appearing opposite the editorial page of the old New York World in the 1920s. ${ }^{8}$ That page was created by legendary editor Herbert Bayard Swope. House columnists presented their views of the arts, culture, and passing scene in the World's "Page Op." Its tone and style differed considerably from the journalism elsewhere in the paper. ${ }^{9}$ Swope was not the first editor to dedicate a separate page to opinion in a daily newspaper. The Chicago Tribune tried a version as early as $1912 .{ }^{10}$ The Washington Post publicly referred to the page of commentary it published opposite the editorial page as the "oped page," in the 1930s, as did the Los Angeles Times in the 1950s and 1960s.'1

While Swope's page provided a basic template, its influence on the development of the Times' op-ed page has generally been over-emphasized.12 Swope did not invite outside contributors to publish on the "Page Op," and his columnists stayed within the conventions of the contemporary genre. A more important antecedent was the newspaper's own 
"Topics of the Times," a column that had been published on Saturdays for decades.

Oakes first seriously proposed the idea of an op-ed page in conversation with publisher Orvil Dreyfoos in the early 1960s. Following Dreyfoos' death in 1963, Oakes' cousin, Arthur Ochs ("Punch") Sulzberger, was named publisher. Sulzberger, like Dreyfoos, was cool to the idea of an op-ed page. Obituaries, a popular revenue-generating feature, had long occupied the page opposite the editorial page. Sulzberger's reticence failed to discourage Oakes; in 1963 and 1964, Oakes discussed his op-ed page idea in public, including at a series of seminars at the Columbia Journalism School.13

Oakes had long argued that newspapers needed more analytical depth and complexity. "The function of newspapers and newspapermen," he concluded, was to "interpret [the] age to the general public." 14 Yet this interpretative responsibility did not mean ostentatious representations of authority; rather, a good journalist needed to be wary of appearing too professorial, elite, and inflexible. When asked to vet a book about the daily operation of the New York Times in 1966, Oakes regretted that the author saw fit "to add to the 'Ivory Tower' image of the editorial page which I have been trying very hard to dispel."15

The "deepest responsibility" of the newspaper, Oakes wrote, was "the same responsibility ... that the college has for its students-the responsibility of making them think." Thus, a fundamental purpose of the editorial page was "to question, to debunk."16 "Diversity of opinion is the lifeblood of democracy," Oakes contended in a 1954 speech. "The minute we begin to insist that every one think the same way we think, our democratic way of life is in danger." ${ }^{17}$ The apparent rise of mass conformity in the United States during the 1950s particularly troubled Oakes. In a May 1963 commencement address, he complained about "mass thought" and called for "more iconoclasm" in the media, politics, and academia. ${ }^{18}$

Oakes's belief that a newspaper most effectively fulfills its social and civic responsibilities by challenging authority, acting independently, and inviting dissent closely echoes the public sphere ideal as described by Jurgen Habermas. There is no evidence that Oakes was aware of-or influenced by-Habermas' ideas. Although written in 1962, the German scholar's book The Structural Transformation of the Public Sphere would not be translated into English until 1989. ${ }^{19}$ Yet, Habermas' public sphere theory is useful for understanding the philosophical principles underpinning Oakes' work. Just as Oakes objected to the inherent stagnation of mass thinking, Habermas found capitalist consumer and political culture exerting "pressure toward conformity with existing conditions." ${ }^{20}$ American intellectuals such as C. Wright Mills, David Reisman, Sloan Wilson, and Dwight MacDonald were expressing similar concerns. ${ }^{21}$ When Oakes appeared on a panel with MacDonald in 1965, the radical critic was surprised to find they agreed on politics and mass culture. "Your puzzlement about what kind of audience a mass mag like the [Saturday Evening] Post was appealing to was just in the line of an essay I've been writing and re- 
writing for twenty years: 'Masscult and Midcult,"' MacDonald wrote to Oakes. $^{22}$

As editorial page editor of the Times, Oakes could address the problem. Wanting to diversify opinion and challenge authority (including his own), Oakes started experimenting with the Topics of the Times column. "I began to... develop... a column that got actual contributors of real articles of the kind of thing that I ultimately wanted to see on an op-ed page." Oakes later remembered. 23 To assist in the transformation of the Topics column into the op-ed page, Oakes recruited Dick Peters, a widely respected editorial page editor, to join the Times. After Peters left, Oakes convinced former Times veteran Herbert Mitgang to return to the newspaper after a stint at CBS News, where he wrote documentaries.

Mitgang, a skilled editor and writer, would play a key role in the development of the op-ed page. With Oakes' encouragement, Mitgang began promoting (and occasionally writing) the Topics column in the format of a classical essay rather than a standard news analysis. Under Mitgang's guidance, the feature started to welcome humorous, ironic, and thought-provoking pieces focused on timeless themes rather than contemporary news analysis. "The essay survives while more immediate dissertations and descriptions of ephemeral events diminish with time," Mitgang would later write, explaining his editorial and stylistic philosophy.24 The emphasis on universal, humanistic themes was in accord with the work of the essayists Habermas referenced as integral to the establishment of Europe's original public spheres. The column combined the more lofty, critical analysis prevalent in European newspapers with traditional American journalistic commentary. 25

Bylines first appeared in 1965, and in 1966, Mitgang noted, "distinguished diplomats and college professors were invited to contribute" for the first time. A year later, fiction writers started to publish non-fiction essays in the space. "Novelists, poets, and playwrights who had not been invited to write serious newspapers essays before, but who were aroused on such moral matters as the American involvement in Vietnam, were given their say in the 'Topics' column," Mitgang explained. "Strong opinion," he argued, required the "special grace" of stylists such as E. B. White and Brooks Atkinson, who demonstrated "what humanists can do with the essay form." 26

New political perspectives were welcomed. Guest contributors regularly expressed their gratitude-and occasional surprise-at being offered space. When the Times published a Topics essay by Adolf A. Berle in 1967, the former New Dealer called Oakes a "gentleman and a scholar," for giving him "space for the little article, especially since I think it does not wholly agree with the views of the Times. ${ }^{27}$ When Mitgang read that Lt. Gen. James M. Gavin supported the nomination of a Republican committed to de-escalating the war in Vietnam, he contacted him to solicit a piece. $^{28}$ In early 1970 ,just before the op-ed page made its debut, Mitgang requested a contribution from the controversial General Curtis LeMay. "Perhaps you would care to comment on the role of the Air Force in Vietnam and whether it should be doing more, less, or something different to expedite the war," he wrote. 29 
Inviting non-journalists to submit creative and engaging essays occasionally proved difficult. "One of the things we discovered rather quickly," Mitgang recalled, "was that ... you just couldn't get really good pieces and good bylines unless you dreamt them up yourself, so we solicited pieces." ${ }^{30}$ In 1969, for instance, Mitgang asked the prominent historian Henry Steele Commager to draft a piece discussing whether the "old revolutionaries [would] approve of the new ones in the country today?" ${ }^{31}$ In early 1969 , Mitgang read a laudatory review of Noam Chomsky's American Power and the New Mandarins and wrote to the MIT Professor. Chomsky's essay soon arrived, but Mitgang found it unusable. He asked Chomsky to cut parts, to summarize, and to paraphrase most of the authors quoted so that "the essay would move along more smoothly," and suggested a "more pointed conclusion about what the scientific community can do about the 'new mandarins' in American society." "I am afraid that I will have to abandon the project, reluctantly," Chomsky wrote after receiving the edits. "For some reason, I find it enormously more difficult to write 700 words than 7000 -a typical professorial defect, I suppose." 32

The New York Herald Tribune had effectively used short essays and articles, contributed by outsiders, on its editorial page for years. Because the Herald Tribune's editorial page was jammed with editorials, letters to the editor, house columnists, and a regular cartoon, the space given to an outside contributor was often 500 words or less. In fact, letters to the editor were occasionally longer. The outside pieces were often arguments for political action. To some extent they clearly anticipated and inspired Oakes' conception. ${ }^{33}$

When the New York Herald Tribune finally succumbed in 1966, Times assistant managing editor Harrison Salisbury dashed off a note to Sulzberger. "A very serious responsibility has been thrust upon us by the death of the Tribune," he wrote, arguing that the Times must consider "providing a platform for responsible conservative opinion." The idea was not simply to insure a more dialectic public sphere; there were, Salisbury pointed out, economic issues at stake as well. "Half our readership-maybe two-thirds-must be responsible, internationalist Republican," he said. ${ }^{34}$

Oakes asked publisher Arthur Sulzberger to revisit the op-ed page idea. ${ }^{35}$ A few weeks later Sulzberger convened a "study group" to look "into the pros and cons of an op-ed page." Sulzberger named Oakes chair, to work with E. Clifton Daniel, managing editor; Scotty Reston, executive editor; and Dan Schwartz, Sunday editor. ${ }^{36}$ They were expected to outline "a general concept of the page, and how it might strengthen the Times." Sulzberger wanted advice on whether the page would need its own editor and staff, whether the material should all be "homegrown" or whether syndicated material would be acceptable, whether a regular political cartoon would be desirable, and whether advertising should be on the page. Concerned largely about business aspects, he asked what the cost of the page would be, and whether the material, if "home-grown," should be syndicated by the Times. ${ }^{37}$

Conceptual and Creative Development 
At the first meeting of the group Oakes said that with the editorial page on one side, and the op-ed page on the other, "the whole broad range of opinion, the conflict of ideas" would play out. Journalists from the Times would be asked to contribute, and articles from other publications would also be published. "I thought it would have a lot of reprints in it and so on from other publications," Oakes later remembered. Oakes said that the page would not be solely political, but rather "a forum for the exchange and clash of ideas...covering a whole broad range of intellectual interests." 38

While Reston, Schwartz, and Oakes were enthusiastic about the page, Harrison Salisbury, sitting in for Clifton Daniel, relayed his supervisor's more negative reaction. Salisbury complained that the new forum would encroach on the interpretative analysis then appearing in the news pages, and he doubted that outside contributions would be of sufficient quality. But the op-ed idea appealed to Salisbury's creativity. He suggested that humor should be welcomed, and agreed with the others that the use of syndicated material should not be dismissed out of hand. As Michael Schudson notes, the forum neatly fit Salisbury's understanding of the pursuit of truth as a collective, not individual, endeavor in which competing perspectives ensure the most public benefit. ${ }^{39}$

The committee met again in October 1966, with Daniel resuming his spot and Salisbury absent. Oakes prepared and circulated a dummy page with excerpts from newspapers and magazines, as well as articles similar to the Topics columns contributed by outsiders. Daniel was impressed but not convinced. At a third meeting in December, the group generally agreed on four key elements: solicited articles, of about 750 words, from a wide variety of writers; reprints from various academic and / or intellectual magazines; interesting speeches and reports that would not otherwise make it into the paper; and the restoration of the daily poem (an idea that Oakes had implemented earlier in his tenure, but had been forced by the publisher to drop). In early 1967 the committee assembled a report. ${ }^{40}$

In preparing for the presentation, Oakes asked Lou Silverstein, the Times' promotion art director, to help improve the dummy page. Silverstein suggested a new, more sophisticated style of artwork. "We wanted the art to be used cleverly," Silverstein later wrote, so that it would be "synthesized with the type and the layout."41 Salisbury described the approach as an attempt to "create an environment which extends and deepens the impact of the word." 42

The presentation, however, failed to impress the publisher. Sulzberger shelved the idea when the tension between the news department under Daniel and the editorial department under Oakes appeared irresolvable. ${ }^{43}$ Although Oakes felt Daniel sabotaged the project, he was undoubtedly aware of considerable strains in the news department. ${ }^{44} \mathrm{At}$ Sulzberger's prodding, in 1967 and 1968 the news department started preparing to publish an afternoon edition with little additional staff. ${ }^{45}$ Reston, Salisbury, and Silverstein continued to work on the op-ed project throughout 1968. In July 1968 Salisbury and Silverstein created a new dummy page for Reston and Sulzberger. ${ }^{46}$ Oakes continued to pester the publisher and other senior executives. 
Sulzberger's decision to mo.ve forward, in the summer of 1969 , was affected by two factors. He had decided to raise the price of the Times from a dime to fifteen cents that fall, and he believed the op-ed page would help to maintain readership.47 In 1968 and 1969, the Times had signed a series of contracts with its unions that forced the publisher to generate new revenue ${ }^{48}$ Sulzberger also wanted to give the noted correspondent Anthony Lewis a regular column on the editorial page, a move that displeased Oakes. By reviving the op-ed idea, Sulzberger hoped to placate his cousin. Clifton Daniel had retired, and Sulzberger thought (mistakenly) that Abe Rosenthal, the paper's new managing editor, might be more amenable to working with Oakes.$^{49}$ Sulzberger and Ivan Veit, the Times; executive vice president, completed the format by insisting that one-quarter of the page be reserved for a "premium" advertisement. ${ }^{50}$

Oakes had always opposed advertising on the page, but he was particularly incensed that corporations like Mobil Oil could buy "their way onto the op-ed page." Everything published there, Oakes argued, should undergo the same editorial review. "We ran innumerable pieces by presidents of every damn oil company in the world," he remembered years later. "So there's no question of not wanting that view appearing, but the idea of paid advertising on that page burnt me up."51 Oakes later remembered only one case-when the Republic of China (Taiwan) purchased the space-in which he and Salisbury were able to convince Veit to remove an advertisement on the grounds of editorial autonomy. ${ }^{52}$

Yet the key sticking point in implementation concerned supervisory authority, not the page's composition. Sulzberger appeared indecisive and, at times, managerially incompetent, when forced to intervene in the conflicts between the editorial department and the news department. He invited Harvard's Chris Argyris, a noted management consultant, to do an organizational review in the hope that it would facilitate communication among senior executives. The Argyris effort, which was detailed in a book he wrote, was a fiasco. ${ }^{53}$ Meetings and retreats only catalyzed anger and recrimination, with Sulzberger ultimately dismissing Argyris and his methods. The embattled publisher settled on Oakes to supervise the op-ed page, but selected Salisbury to be the page's editor. Mitgang was named Salisbury's deputy, and Bob Melson became art director with part-time help from picture editor Sally Forbes. ${ }^{54}$ The op-ed operation began in earnest in June 1970.

With a team in place, the two top editors began assessing possible contributors, discussing ways the page could be made unique, and establishing methods for handling unsolicited manuscripts. Salisbury and Mitgang canvassed both outsiders and Times employees for ideas. Salisbury's notes and correspondence from this period offer revealing glimpses of his thoughts at the time. One list of ideas included asking Gus Hall of the Communist Party USA to explain "U.S. Communist priorities these days," and having Robert Welch answer the question: "the John Birchers are flourishing, yes?" Following up on Mitgang's use of fiction writers for the Topics column, Salisbury wondered whether Vladimir Nabokov might be induced to answer "what does America 
look like to a novelist from afar?" and whether Robert Penn Warren would be willing to describe "the South of Geo. Wallace." ${ }^{55}$ For candid evaluations of conservative contributors, Salisbury phoned John Leonard and William F. Buckley. He asked Charlotte Curtis, a veteran Times editor (and his successor as op-ed page editor), to suggest feminists. ${ }^{56}$ He considered contacting the esteemed naval historian Samuel Eliot Morison to do "a piece on Columbus as the first astronaut.... This would be comparing the negative reaction and the lack of support which was Columbus' fate after returning from his great adventure with what has happened to our space program after it has achieved its great success." 57

\section{Launching} the $O p-E d$ Page
The Times first publicly announced the new feature on July 28, 1970. Sulzberger's news release, which omitted any mention of artwork or advertising, emphasized the "greater opportunity ... for American and foreign writers to put forward their ideas in the form of original signed articles." He added, "points of view in disagreement with the editorial position of the Times will be particularly welcomed." 58

The op-ed page debuted on September 21, 1970, with an Anthony Lewis column and several outside contributions. An essay on U.S. policies in Asia by W.W. Rostow, a former foreign affairs aide to President Johnson, was paired with an observational piece, "Peking in Autumn," by Han Suyin, a Chinese writer. Suyin's piece was placed next to a photograph of Tiananmen Square. Gerald W. Johnson, a contributing editor of the New Republic, offered a biting assessment of the "exotic" vocabulary Vice President Spiro T. Agnew used to attack liberal critics of the Nixon administration. A simple caricature showed Agnew fuming with anger. A U.S. Steel advertisement was placed on the bottom right side of the page..$^{59}$

Over the next six months, Salisbury, Mitgang, and Jean-Claude Suares, who soon replaced Melson as op-ed art director, published startling illustrations and thought-provoking essays. Contributions from outside the field of journalism drew attention and sparked controversy. Surveys showed the page being read more than any other part of the paper. ${ }^{60}$ The artwork and graphic design attracted attention, both in the industry and the art world. Suares was asked to mount an exhibition in France, and within three years two books focusing upon op-ed art appeared. ${ }^{61}$ Within two years, op-ed pages were established at the Chicago Tribune, Boston Globe, and elsewhere. ${ }^{62}$ Times op-ed essays were republished in four books in four years. ${ }^{63}$

Yet, even as the format became popular, Salisbury and Mitgang found that they still needed to define the essence of an op-ed essay for contributors. "These essays run 700 words," Mitgang explained to novelist Walker Percy, "and appear opposite the editorial page of the Times. The most successful pieces have been highly individualistic, opinionated, and pungent." Mitgang added, "you will not get arrested if the piece is also witty." 64

The page was remarkably cost-effective; most of the employees (aside from Mitgang and Salisbury) were borrowed from other parts of 
the paper. The Times paid a pittance-between $\$ 125$ and $\$ 150$-for pieces by famous figures that could then be syndicated throughout the United States. Such stinginess occasionally became obvious to both authors and employees. "I do think a great newspaper like the Times should pay more than $\$ 125$ for a piece on the editorial page," complained Arthur Schlesinger, Jr., in 1970. ${ }^{65}$ Suares regularly bemoaned the insufficiency of the art budget and pay scale for artistic contributions. ${ }^{66}$ Cost control would become a major issue throughout 1971; Oakes reminded Salisbury and staff several times about the need for austerity in entertainment expenses, telephone calls, and other discretionary spending. ${ }^{67}$

Such tight control over costs helped produce extraordinary financial results. A review completed in mid-1971 revealed that the first six months of op-ed operation produced a net profit of $\$ 112,000$ on $\$ 264,900$ of revenues. The editors had spent $\$ 21,800$ on art, $\$ 54,300$ on articles, and $\$ 2,300$ on photographs. ${ }^{68}$ The results were remarkable for a recessionary period. A comparison of the first nine months of 1969 to the same period in 1970 showed net operating income of the New York Times Company declining from $\$ 10.2$ million to $\$ 6.8$ million. Classified advertising fell $18.3 \% .^{69}$ The Op Ed page's premium advertisements, usually written like the adjacent editorials and essays, accounted for $\$ 244,400$ in revenue in the first six months. ${ }^{70}$

After the page had existed for almost a year, Salisbury solicited analyses from John Van Doom and David Schneiderman who had been on loan from other departments to assist in the development. "My single biggest complaint is our propensity towards 'names,"' Schneiderman said. "I do understand the need for establishment opinion, but we do have too much of it. It is usually of very poor quality. Considering the large number of excellent articles that sit around for months, it is a shame that we run so much junk by the famous."71 Van Dom agreed. "I would like to insist upon excellence from all comers as the standard for getting on the op-ed page," he wrote. "We should forget about names as names-and pursue good writing." 72

Outside assessments of the op-ed page in its first few years were mixed. "Although some of the political contributions have been a bit pedantic, other offerings have produced delight, drama, and deliberate outrage," Time commented. "Inevitably, op-ed's quest for originality sometimes falls flat," the reviewer said, adding that "contributions from both extremes of the political spectrum remain the most turgid in style." ${ }^{73}$ The page's preference for radical right and left viewpoints, Carl Gershman argued in Commentary, distorted political reality. "That the Youth Candidate in 1972 lost the youth vote to Richard Nixon was a development which could only have been incomprehensible to any reader of the op-ed page who took its picture of the world seriously," he observed. ${ }^{74}$

In the middle of the page's second year, Oakes assembled an internal committee to review its performance, and to respond to a list of his chief concerns. Some of the questions were: "Should the op-ed coordinate in any way with the editorial page?" "Does op-ed lean too hard on 
'causes,' viz., Vietnam, prison reform, Russian exiles, etc.?" "Is there insufficiency of theoretical articles, genuine, 'think pieces,' advances of new ideas or doctrines, or too much?" "Does op-ed lean too heavily on extremists for sensational or striking presentations-either of left or right?" "Is there genuine diversity of opinion on the op-ed page-or is it more apparent than real?" 75 After meeting throughout the spring of 1972 the committee concluded "No significant suggestions for radical change in the op-ed formula or execution were developed." The members suggested exploring the possibility of a stand-alone weekly op-ed section and asked for a reconsideration of the advertising format. "Every committee member shared the frequently expressed criticism that corporations were seeking to get a 'ride' on the issue-conscious public which is attracted to the page," Salisbury reported. ${ }^{76}$

\section{Child}

of Its

Times

Herbert Mitgang later called the 1960s the era of "panic-button America," explaining that the transformation of the Topics column was intended to provide much-needed analysis and perspective. ${ }^{77}$ In the wake of the sixties, the Times and other newspapers worked on their forums of opinion as industry competition decreased and political conflicts increased. The Washington Post, for instance, revamped its op-ed page one month before the Times debuted its version. But the Post's version differed considerably from the Times'. The Post announced both the expansion of the Letters to the Editors section and plans for pieces by "outsiders with expertise of one sort or another." The Post's op-ed page had no ads and no artistic component. $7^{8}$

Lou Silverstein's design team at the Times used the op-ed page to successfully sell Sulzberger on a "revolution in content and design" that would sweep newspapers throughout the United States in the 1970s. Silverstein later credited the op-ed page with being the "watershed" moment. ${ }^{79}$

The op-ed page also was a key element in the expansion of political commentary in American newspapers. Oakes wanted to diversify opinion and to contribute to a more robust public sphere. External pressures on the Times to diversify political discussion had grown in the late 1960s. Agnew's famous Des Moines speech criticizing eastern liberal media was delivered in November 1969, several months after Sulzberger decided to start the page. Years later Oakes would point to a July 1970 Topics piece by Agnew to illustrate his enthusiastic willingness to publish oppositional pieces. ${ }^{80}$

In apparent response to social turmoil and complaints about the media being negative, left-leaning, and out of touch with the "silent majority," broadcasters also sought additional perspectives. CBS News sent Charles Kuralt On the Road across America for quaint feature stories. At NBC News, a new analytical segment, "Crosstalk," debuted in 1968 on The Huntley-Brinkley Report. A year later the network assigned veteran reporters Jack Perkins and Tom Pettit to profile average Americans in the Midwest. ${ }^{81}$ One survey of local television stations showed that of 123 stations, 115 said "they had begun a serious search for more 'good news' items" in this period. ${ }^{82}$ 
Lou Silverstein remembered that the late 1960s were "a bad time for the country but a good time to start the op-ed page." ${ }^{83}$ Similarly, Harrison Salisbury called the feature a "child of its times." He called the period an "age of skepticism," in which "not one institution in American society escaped reexamination." ${ }^{84}$ During this tumultuous time, the number of daily newspapers in New York City declined. The Times lost its chief competitor when the Herald Tribune failed. "We knew we had to attract readers of the old Herald Tribune, "Salisbury noted in discussing the op-ed innovations at the Times. ${ }^{85}$

Oakes wanted credit for establishing the op-ed page. 'Tm sick and tired of the distortions regarding origins of the op-ed page," he once told an interviewer. "I have a duty ... to set the record straight. I fought for years-alone-to get the op-ed idea accepted, and when it finally did materialize ... it embodied almost precisely the concept I originally laid out." ${ }^{86}$ Upon hearing a rumor that Salisbury had claimed to be the inventor of the feature in a Los Angeles Times interview, Oakes dashed off a vehement letter of protest to his former colleague. ${ }^{87}$ While Oakes must be recognized as the prime mover, the page did not "almost precisely" embody his original ideas. His initial desire to open up political and cultural discussion would be transformed in the process of implementation. Others took his outline and filled it in with ideas of their own.

The op-ed synthesis that finally emerged effectively wedded the philosophical notion of a public sphere and the practical reality of a newspaper needing to be profitable. Yet, in the broadest sense, both Oakes and Jurgen Habermas can be described as somewhat nai:Ve idealists whose understanding of a unitary, inclusive, and diverse public sphere obscures the more contentious reality of negotiation amongst multiple publics in any given society. Media scholars have critiqued Habermas's theory on these and other grounds; for instance, his privileging of reason, and his disregard for alternative modes of public social, civic, and political participation have been cited to challenge the validity of his theoretical (and historical) model. ${ }^{88}$

Despite such criticisms, scholars can effectively apply public sphere theory to news media. Karin Wahl-Jorgensen's study of letters to the editor notes that Habermas' scholarship "contains a rich vocabulary for interrogating the interplay of mass media and democracy." In particular, Wahl-Jorgensen credits Habermas with developing a sophisticated model acknowledging the dynamic of multiple interacting publics. "If we thus pluralize 'the public sphere,"' Wahl-Jorgensen writes, "we can sensibly understand forums such as letters to the editor as such public counterpoints, where representatives of all the public spheres share their ideas, in the civil forms of discursive writing or talking, on anything from gun control and abortion to bilingual education." Media forums inviting outside participation thus "can be seen as coordinating and integrating the variegated publics by providing an intellectual watering hole where destructive conflict can temporarily be set aside to accommodate a range of voices and interests that are allowed to speak 
richly and substantively." ${ }^{89}$ Such a forum is precisely what Oakes sought in the op-ed page. The exchange and interplay of new ideas, both Oakes and Habermas believed, could provide an antidote to the homogenizing effects of the commercial mass media.

\section{NOTES}

1. "Op. Ed. Page," New York Times, September 21, 1970, p. 42.

2. Edwin Diamond, Behind the Times: Inside the New York Times (New York: Random House, 1993); Joseph C. Goulden, Fit to Print: A.M . Rosenthal and his Times (Secaucus, NJ: L. Stuart, 1988); Jerelle Kraus, All the Art That's Fit to Print (and Some That Wasn't): Inside The New York Times OpEd Page (New York: Columbia University Press, 2009); Herbert Mitgang, "The Journalistic Essay," in America at Random, ed. Herbert Mitgang (New York: Coward-McCann, Inc., 1969); Herbert Mitgang, Newsmen in Khaki: Tales of a World War II Soldier (Lanham, MD: Taylor Trade Publications, 2004); James Reston, Deadline: A Memoir (New York: Times Books, 1992); Harrison E. Salisbury, "Introduction," in The Eloquence of Protest; Voices of the 70's, ed. Harrison E. Salisbury (Boston: Houghton Mifflin, 1972), xixvii; Harrison E. Salisbury, A Journey for Our Times: A M emoir (New York: Harper \& Row, 1983); Harrison E. Salisbury, "Introduction," in The Indignant Years: Art and Articles from the Op-Ed Page of the New York Times, ed. Harrison E. Salisbury (New York: Crown / Arno Press, 1973), 5-6; JeanClaude Suares, Art of the Times (New York: Universe Books, 1973); Gay Talese, The Kingdom and the Power (New York: World Pub. Co., 1969); Susan E. Tifft and Alex S. Jones, The Trust: The Private and Powerful Family Behind the New York Times (Boston: Little, Brown and Company, 1999).

3. Chris Argyris, Behind the Front Page: Organizational Self-Renewal ina Metropolitan News paper (San Francisco: Jossey-Bass Publishers, 1974).

4. Kraus, All the Art That's Fit to Print.

5. David Croteau and William Hoynes, The Business of $M$ edia: Corporate Media and the Public Interest (Thousand Oaks, CA: Pine Forge Press, 2006, c.2001), xi-xii; Ben H. Bagdikian, The Media Monopoly, 5th ed. (Boston: Beacon Press, 1997); The Business of Journalism, ed. William Serrin (New York: The New Press, 2000).

6. Jurgen Habermas, The Structural Transformation of the Public Sphere: An Inquiry Into a Category of Bourgeois Society, trans. by Thomas Burger, with the assistance of Frederick Lawerence (Cambridge, MA: MIT Press, 1991), 27-56.

7. Reminiscences of John B. Oakes (1978), 267, 275 in the Oral History Research Office Collection of the Columbia University Libraries; Francois Charles-Roux, "Suez Canal Company's View of the Seizure," New York Herald Tribune, August 9, 1956, p. 14.

8. Reminiscences of John B. Oakes (1978), 268.

9. On Swope's Page Op, see: Ely Jacques Kahn, The World of Swope (New York: Simon \& Schuster, 1965), 260-77; Richard Kluger, The Paper: The Life and Death of the New York Herald Tribune (New York: Alfred A. Knopf, 1986), 256-57;Alfred Allan Lewis, Man of the World: Herbert Bayard 
Swope: A Charmed Life of Pulitzer Prizes, Poker and Politics (Indianapolis,

IN: Bobbs-Merrill, 1978), 82-86.

10. Diamond, Behind the Times, 293.

11. See, for instance: "Op-Ed Page," Washington Post, June 14, 1938, pp. 1, 9; Gene Sherman, "Our Columnist Finds New Cozy Corner," Los Angeles Times, March 2, 1959, sec. B, p. 5; James Bassett, "The Battle of the Analysts," Los Angeles Times, November 26, 1967, p. 6.

12. Eric Alterman, Sound and Fury: The Washington Punditocracy and the Collapse of American Politics (New York: HarperCollins Publishers, 1992), 131.

13. Richard T. Baker to Mr. John B. Oakes, February 26, 1964; Richard T. Baker to Mr. John B. Oakes, February 4, 1963. Reel 3, Segment 12, Microform 96, John B. Oakes Papers, Wisconsin Historical Society Archives [Hereafter: JBO-WHSA].

14. John B. Oakes, "The Newspaper Job," Nieman Reports 11 (April 1957): 2; John B. Oakes, "Princeton - Mar 7 '58," "Speech Notes," Reel 4, Microform 96, JBO-WHSA.

15. J.B.O. to Miss Ruth Adler, June 22, 1966, Reel 5, Microform 96, JBO-WHSA; Ruth Adler, A Day in the Life of the New York Times (Philadelphia: Lippincott, 1971).

16. John B. Oakes, "Responsibility of the Press," Speech to the Bryn Mawr Alliance for Political Action, February 25, 1963, 10, "Speech Notes," Reel 4, Microform 96, JBO-WHSA.

17. Speech at Collegiate School, May 7, 1954, 4, "Speech Notes," Reel 4, Microform 96, JBO-WHSA.

18. John B. Oakes, "Smashing the Cliche: Commencement Address at Pomona College, June 9, 1963," 4, Reel 4, Microform 96, JBO-WHSA.

19. Habermas and the Public Sphere, ed. Craig Calhoun (Cambridge, MA: The MIT Press, 1992), vii.

20. Habermas, The Structural Transformation of the Public Sphere, 215.

21. Dwight MacDonald, Against the American Grain (New York: Random House, 1962); C. Wright Mills, White Collar: The American M iddle Classes (New York: Oxford University Press, 1956, c1951); David Riesman, The Lonely Crowd: A Study of the Changing American Character (New Haven, CT: Yale University Press, 1950); William H. Whyte, The Organization Man (New York: Simon \& Schuster, 1956); Sloan Wilson, The Man in the Gray Flannel Suit (New York: Simon and Schuster, 1955).

22. Dwight MacDonald to Mr. Oakes, June 16, 1965, Reel 5, Microform 96, JBO-WHSA.

23. Reminiscences of John B. Oakes (1978), 279.

24. Herbert Mitgang, "The Journalistic Essay," in America at Random, ed. Herbert Mitgang (New York: Coward-McCann, Inc., 1969), 15.

25. Elisabeth Le, "Information Sources as a Persuasive Strategy in Editorials: Le Monde and the New York Times," Written Communication 20 (October 2003): 478-510.

26. Mitgang, "The Journalistic Essay," 18-19.

27. Adolf A. Berle to Mr. John Oakes, January 20, 1967, Reel 5, Folder B, 1963-1967, Microform 96, JBO-WHSA; Adolf A. Berle, "Topics: Appraisal of LBJ By an Old New Dealer," New York Times, January 14, 
1967, 30.

28. Herbert Mitgang to Gen. James M. Galvin, September 13, 1967, Gen. James M. Galvin to Herbert Mitgang, September 18, 1967, "Op Ed Correspondence - FO - G," Box 15, Herbert Mitgang Papers, New York Public Library [Hereafter: HM-NYPL].

29. Herbert Mitgang to General Curtis E. LeMay, January 12, 1970, "Op

Ed Correspondence -L," Box 16, HM-NYPL.

30. Herbert Mitgang interview with author, October 2, 2008, 2.

31. Herbert Mitgang to Professor Henry Steele Commager, January 20, 1969, "Op Ed Correspondence - Cli - Co," Box 15, HM-NYPL; Henry Steele Commager, "Topics: Revolution, 1776 and 1969," New York Times, July $5,1969,18$.

32. Herbert Mitgang to Mr. Noam Chomsky, January 24, 1969; Herbert Mitgang to Mr. Noam Chomsky, March 4, 1969; Noam Chomsky to Mr. Herbert Mitgang, April 18, 1969, "Op Ed Correspondence - Ca-Ch," Box 15, HM-NYPL.

33. Reminiscences of John B. Oakes (1978), 267-8.

34. HES [Harrison E. Salisbury] to Mr. A. 0. Sulzberger, August 18, 1966, Folder 72, Box 538, Harrison Salisbury Papers, Columbia University Rare Book \& Manuscript Library [Hereafter: HSP-CU].

35. Reminiscences of John B. Oakes (1978), 275.

36. When a scheduling conflict precluded the participation of $\mathrm{E}$. Clifton Daniel from attending the initial meeting, Harrison Salisbury replaced him. See: A.O.S. [Arthur O. Sulzberger] to Mr. Oakes, September 26, 1966, and A.0.S. to Mr. Salisbury, September 26, 1966, Folder 72, Box 538, HSP-CU.

37. A.O.S. [Arthur 0. Sulzberger] to Mr. Daniel, Mr. Reston, Mr. D. Schwartz, September 21, 1966, Folder 72, Box 538, HSP-CU.

38. Reminiscences of John B. Oakes (1978), 277.

39. Reminiscences of John B. Oakes (1978), 276-78, 357; Michael Schudson, The Power of News (Cambridge, MA: Harvard University Press, 1995), 94-110.

40. Reminiscences of John B. Oakes (1978), 282-85.

41. Louis Silverstein, Newspaper Design for the Times (New York: Van Nostrand, 1990), 26-27, 39.

42. Harrison E. Salisbury, "Introduction," in The Indignant Years: Art and Articles from the Op-Ed Page of the New York Times, ed. Harrison E. Salisbury (New York: Crown / Arno Press, 1973), 6.

43. Reston, Deadline, 363; Diamond, Behind the Times, 293.

44. Reminiscences of John B. Oakes (1978), 291.

45. John C. Merrill, The Elite Press: Great Newspapers of the World (New York: Pitman Publishing Corporation, 1968), 263-72.

46. The dummy page and 1968 project are mentioned in H.E.S. [Harrison E. Salisbury] to Mr. Oakes, June 15, 1970, Folder 5, Box 544, HSP-CU.

47. "An Extra Nickel's Worth," Time, June 21, 1971, 36. url: http: / / www.time.com / time / magazine / article /0,9171,905194-2,00.html (accessed January 20, 2009); David Shaw, "Newspapers Offer Forum to Outsiders," Los Angeles Times, October 13, 1975, sec. B, p. 3. 
48. Shaw, "Newspapers Offer Forum to Outsiders," sec. B, pp. 1, 3, 16.

49. Reminiscences of John B. Oakes (1978), 291-293, 298.

50. Silverstein, Newspaper Designfor the Times, 27.

51. Reminiscences of John B. Oakes (1978), 298.

52. Reminiscences of John B. Oakes (1978), 296-297.

53. Argyris, Behind the Front Page, 153-160; Diamond, Behind the Times, 98-100; Tifft and Jones, The Trust, 463.

54. Silverstein, Newspaper Designfor the Times, 27.

55. "Preliminary Ideas" (n.d.), Folder 8, Box 249, HSP-CU.

56. "John Leonard's Suggestions" and "Bill Buckley's Suggestions," handwritten notes in Folder 8, Box 249, HSP-CU; Charlotte Curtis to Harrison Salisbury, June 23, 1970, Folder 8, Box 249, HSP-CU.

57. Harrison Salisbury to Mr. Mitgang, September 4, 1970, "Op Ed Correspondence, Mo-P," Box 16, HM-NYPL.

58. "Times Will Offer Daily Forum Page," New York Times, July 29, 1970, p. 39.

59. W.W. Rostow, "United States and Asia: I," New York Times, September 21, 1970, p. 43; Han Suyin, "Peking in Autumn," New York Times, September 21, 1970, p. 43; Anthony Lewis, "The Guns of September," New York Times, September 21, 1970, p. 43; Gerald W. Johnson, "S.T. Agnew Is No H.L. Mencken," New York Times, September 21, 1970, p. 43.

60. Diamond, Behind the Times, 277.

61. Art of the Times, ed. Jean Claude Suares (New York: Universe Books, 1973); Salisbury, ed., The Indignant Years.

62. Shaw, "Newspapers Offer Forum to Outsiders," sec. B, pp. 3, 16.

63. Salisbury, ed., The Eloquence of Protest; Salisbury, ed., The Indignant Years; Suares, Art of the Times; Capitalism, The Moving Target, ed. Leonard Silk (New York: Praeger, 1974).

64. Herbert Mitgang to Mr. Walker Percy, March 29, 1971; Walker Percy to Mr. Herbert Mitgang, March 31, 1971, "Op Ed Correspondence Mo-P, "Box 16, HM-NYPL.

65. Arthur Schlesinger, Jr., to Herbert Mitgang, April 22, 1970, "Op Ed correspondence, Ro-Sh," Box 16, HM-NYPL.

66. Harrison Salisbury to J.C. Suares, November 9, 1971, Folder 26, Box 551, HSP-CU.

67. J.B.O. to Mr. Salisbury, October 11, 1971; J.B.O. to Editorial Staff, November 2, 1971, Cataloged Correspondence, Box 8, HSP-CU.

68. Ivan Veit to Mr. Sulzberger, July 30, 1971, Folder 26, Box 551, HSPCU.

69. "The New York Times Trims Some Edges," Business Week, January 2, 1971, 17.

70. Ivan Veit to Mr. Sulzberger, July 30, 1971, Folder 26, Box 551, HSPCU.

71. David Schneiderman, "Schneiderman's Year End Report on the State of Op Ed," (n.d.), 1-2, Folder 26, Box 551, HSP-CU.

72. John Van Doorn to Mr. Salisbury, September 24, 1971, Folder 26, Box 551, HSP-CU.

73. "An Extra Nickel's Worth," 36. 
74. Carl Gershman, "The Times' Op-Ed Page: Both Ends Against the Middle," Commentary, April 1973, 46.

75. John B. Oakes, "Editorial Pages Examination," March 6, 1972, Folder 28, Box 551, HSP-CU.

76. Harrison E. Salisbury to Mr. Oakes, May 9, 1972, "Op Ed Task Force," Folder 28, Box 551, HSP-CU.

77. Mitgang, "The Journalistic Essay," 19.

78. "F.Y.1.," The Washington Post, Times Herald, August 10, 1970, sec. A, p. 18.

79. Silverstein, Newspaper Designfor the Times, 3, 27.

80. Reminiscences of John B. Oakes (1978), 280; Spiro T. Agnew, "Topics: On Dividing the Country," New York Times, July 11, 1970, p. 19.

81. Garrick Utley, You Should Have Been Here Yesterday: A Life in Television News (New York: Public Affairs, 2000), 137-38.

82. Edward Bliss, Now The News: The Story Of Broadcast Journalism (New York: Columbia University Press, 1991), 410.

83. Silverstein, Newspaper Designfor the Times, 28.

84. Salisbury, "Introduction," 5.

85. Shaw, "Newspapers Offer Forum to Outsiders," sec. B, p. 3.

86. Reminiscences of John B. Oakes (1978), 360.

87. John B. Oakes to Mr. Salisbury, May 20, 1976. H.E.S. to John B. Oakes, May 21, 1976, Cataloged Correspondence, Box 8, HSP-CU.

88. See, for instance: Tanni Haas and Linda Steiner, "Public Journalism as a Journalism of Publics: Implications of the Habermas-Fraser Debate for Public Journalism," Journalism 2 (August 2001): 123-47; Michael Huspek, "Habermas and Oppositional Public Spheres: A Stereoscopic Analysis of Black and White Press Practices," Political S tudies 55 (December 2007): 821-43.

89. Karin Wahl-Jorgensen, "Ensuring Richness and Diversity of Representation in the Public Sphere: Mass Media as Forums for Democratic Debate," Journal of the Northwest Communication Association 27 (spring 1999): 25-26, 34. See also: Karin Wahl Jorgensen, "Understanding the Conditions for Public Discourse: Four Rules for Selecting Letters to the Editor," Journalism Studies 3 (February 2002): 69-81. 